\title{
Hybrid Electrical System Optimization of Remote Island using HOMER
}

\author{
Adrian Mansur 1,a,* \\ ${ }^{1}$ PT PLN (Persero) UPDL Makassar, Jl. Poros Malino, Gowa, 92119, Indonesia \\ a, ${ }^{*}$ adrianmansur@pln.co.id (Corresponding author)
}

\begin{abstract}
Renewable energy is an important solution in improving access to electricity, especially in isolated areas including the utilization of solar power however intermittency is becoming the main challenge that is faced in the application of Solar Power Plant (SPP). Hybrid system implementation becomes a strategy in an effort to improve system reliability based on the variation in load and intermittency of SPP. Salemo Island is one of the areas that has utilized SPP as one of the sources of electricity energy, but its operation has not been optimal as the load increases, therefore, a study was conducted to optimize the hybrid electrical system based on the current existing conditions. The results of the study showed that with the addition of SPP capacity of $200 \mathrm{kWp}$ and the addition of batteries as much as 120 units, it could obtained an optimal Leveled Cost Of Energy (LCOE) value of $1,306 \mathrm{IDR} / \mathrm{kWh}$ and operating costs of 450 million with a Net Present Cost (NPC) of 8.4 billion and a capital cost of 3.2 billion. Another option is the addition of SPP $150 \mathrm{kWp}$ with a lower capital cost value of 2.02 Billion, but greater than the aspect of operating cost of 883 million and LCOE of 1,897 Rp/ kWh.
\end{abstract}

Keywords—; Hybrid; LCOE; Solar

\section{Introduction}

Renewable energy is the most important solution for an increasing universal population that demands reasonable access to electricity while reducing the need for fossil fuels [1]. The continued uses of fossil fuels have catastrophic impacts on the environment. thus, currently the utilization of renewable energy in electrical systems or hybridization with alternative energy can reduce the emissions of harmful gases produced by fossil fuels [2].
The main reason for using hybrid or combined systems from different energy sources is to enable overall improvement of system reliability, capable in supplying power efficiency and to reduce electrical energy storage [3].

Photovoltaic hybrid system combination (PV)-batterydiesel requires technical knowledge, economics and preliminary studies for design, optimizing load options according to profile, assessing simulation consumption and performance before system installation and implementation. Each of these items requires computer data and tools to achieve it [4].

Under low load conditions, diesel generators are turned off and energy supplied by PV systems. However, under medium load conditions, diesel generators are allowed to operate at optimal loading to meet the load. During the operation, it stores excess energy, if any. Under peak load conditions, diesel generators and PV systems both supply power to meet the required loads [5].

Hybrid power systems are considered an effective option in terms of low-cost power generation, noise reduction and gas emissions, better and reliable electricity supply using PV as a primary resource and having diesel generators or networks as back-up resources [6].

According to Nurmela, et al (2019) [7], a combination of Solar Power Plant (SPP) and Diesel Power Plant could reduce the Cost of Power Generation (BPP) through the penetration of SPP. The study results showed that there is an improvement in the power system optimization after the penetration of SPP. 
The main problems of power plants using hybrid power systems are the variations in renewable resources (wind speed and solar radiation) and the variations in load demand. Therefore, the main focus in the design of hybrid power systems that use renewable energy sources is the selection of the best components for systems that can meet the demand for load and reliability economically [8].

In this study, the Hybrid Optimization Model for Electric Renewables (HOMER) was used to determine the optimal combination of the system components that would result in the lowest cost. HOMER simulates system operation by providing energy balance calculations for every 8,760 hours of the year. If the system contains batteries and diesel generators, HOMER can also decide for each hour, whether the diesel generator is operating and whether the battery is charged or discharged. Next, HOMER determines the best configuration of the system and then estimates the installation and operating costs of the system over its lifetime [9][10][11][12].

Salemo Island is one of the islands located in the district of Pangkajene Islands, precisely in Liukang Topabbiring sub district with coordinates $-04.689561^{\circ}$, $119.468774^{\circ}$. Currently, Salemo Island's electrical system is supported by a $200 \mathrm{kVA}$ diesel power plant system and a $150 \mathrm{kWp}$ solar power plant that operates alternately manually with 2 units of Diesel. Figure 1 shows a map of Salemo island location.

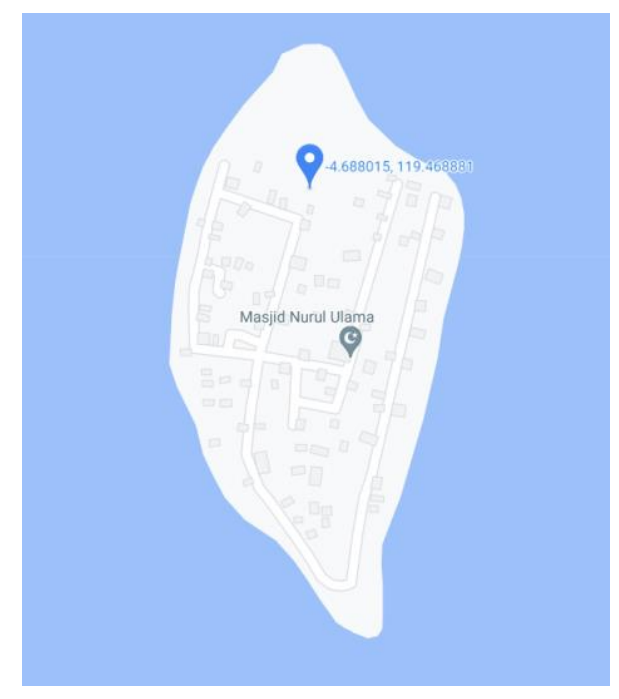

Figure 1. Map of Salemo Island
As for the potential of solar radiation based on solar radiation potential data from the Global Solar Atlas shown in figure 2, the island of Salemo has the potential at global tilted irradiation at optimum angle of 5.329 $\mathrm{kWh} / \mathrm{m}^{2}$ per day. Figure 2 shows the radiation potential on Salemo Island.

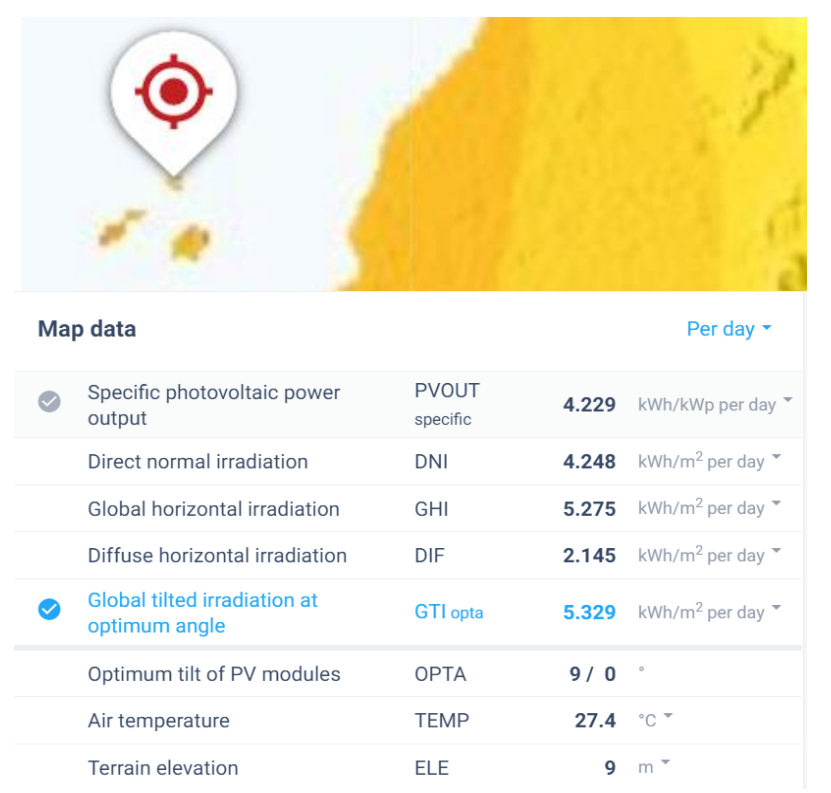

Figure 2. Salemo island radiation potential [13].

This study aims to optimize the capacity of SPP and Battery to be conducted hybrid with existing DPP based on the current load conditions using HOMER.

\section{Research Methodology}

This research was conducted on existing electrical systems by recalculating the optimal needs of existing SPP capacity to be conducted hybrid with existing diesel system based on current load conditions. Furthermore, an analysis of the financial review of the hybrid dieselSPP-battery system in the electricity system of Salemo Island is conducted. Figure 3 shows the flowchart of the steps this study performed. 


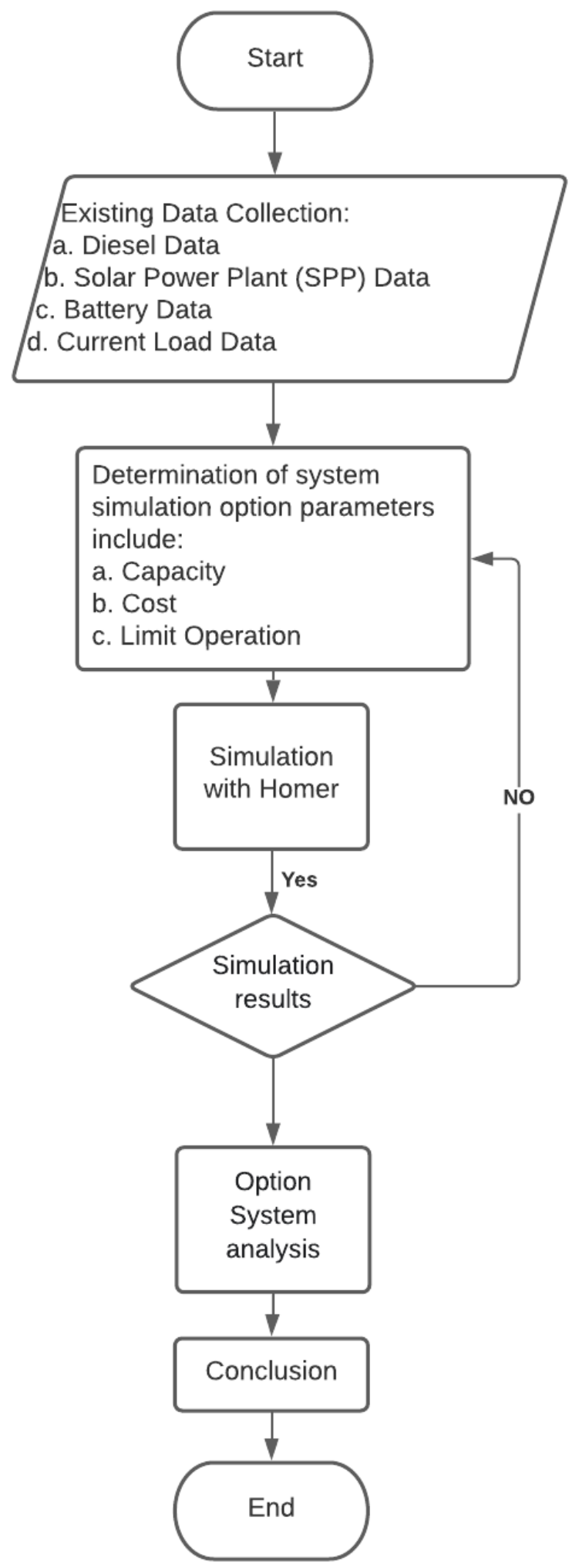

Figure 3. Flowchart Research

\section{A. Input Parameter}

a. Load Profile

The total energy demand of Salemo island is $1.528 \mathrm{kWh}$ with a peak load of about $89 \mathrm{~kW}$. The load profile can be seen in Figure 4.

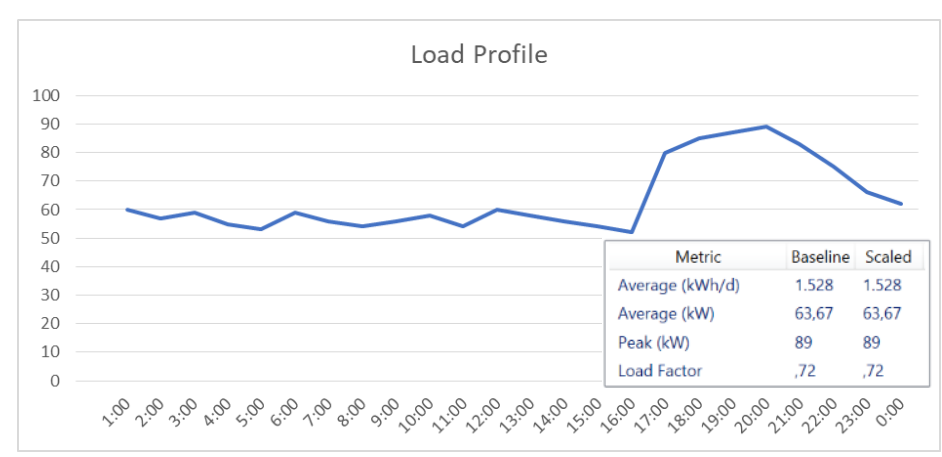

Figure 4. Load Profile

\section{b. Potential Data}

The potential of solar radiation on the Salemo Island is shown in HOMER application namely Monthly Average Solar Global Horizontal Irradiance (GHI) can be seen in figure 5 .

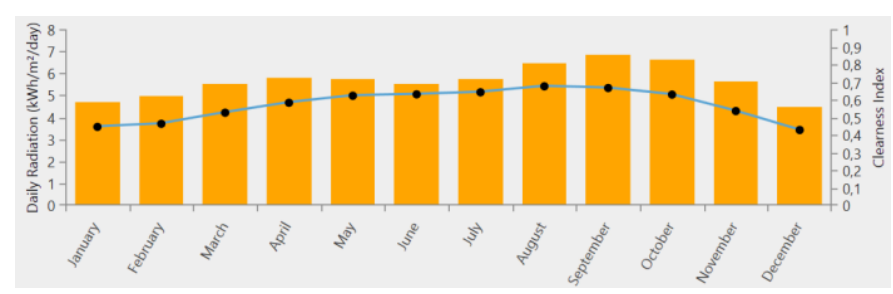

Figure 5. Global Horizontal Irradiance

c. System Design

The system design shown on HOMER consists of (see Figure 6):

- Load is based on the current load conditions on Salemo island of $1,528 \mathrm{kWh} /$ day.

- Diesel is designed based on the capacity currently installed on Salemo island's electrical system.

- Existing SPP is a plant that is currently installed on Salemo island with a capacity of $150 \mathrm{kWp}$

- Additional SPP is a plan to increase the capacity of SPP to meet the needs of the system based on current conditions. 
- The battery uses Lead Acid that corresponds to the current type of battery, and it is assumed that all batteries are replaced

- Inverter is a bidirectional type inverter to convert the amount of electricity from both DC$\mathrm{AC}$ and AC-DC.

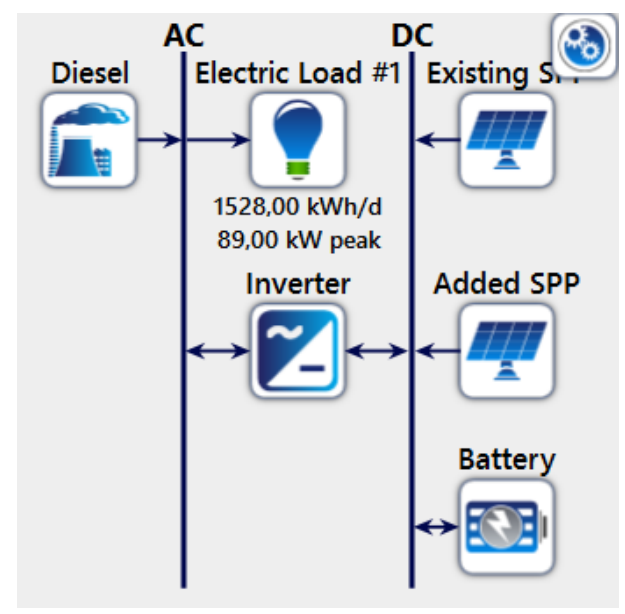

Figure 6. System Design HOMER.

Based on the schematic in the figure 6 , further determination of the parameters and specifications of each component in the simulation as shown in the Table 1.

Table 1. Specification System

\begin{tabular}{lc}
\multicolumn{1}{c}{ Parameter } & Specification \\
\hline Capacity & \\
Minimum Load & $100 \mathrm{~kW}$ \\
\hline Capital Cost & $25 \%$ \\
\hline Replacement Cost & 0 \\
\hline O\&M Cost & 0 \\
\hline Capacity & 0 \\
\hline Lifetime & $150 \mathrm{kWp}$ \\
\hline Capital Cost & 10 Years \\
\hline Replacement Cost/kW & 0 \\
\hline
\end{tabular}

DOI : $\underline{\text { http://dx.doi.org/10.31963/intek.v8i2.2962 }}$
O\&M Cost

\begin{tabular}{lc} 
& Added PV \\
\hline Capacity & $50,100,150,200(\mathrm{kWp})$ \\
Lifetime & 20 Years
\end{tabular}

\begin{tabular}{lc} 
Capital Cost/kW & IDR $8,400,000$ \\
\hline Replacement Cost & IDR 6,000,000
\end{tabular}

\begin{tabular}{lcc} 
O\&M Cost & 0 \\
& Battery & \\
Capacity & 5,10 (String) \\
\hline Lifetime & 5 Years
\end{tabular}

Lifetime 5 Years

\begin{tabular}{ll}
\hline Capital Cost/pcs & IDR 6,400,000 \\
\hline Replacement Cost & IDR 5,000,000
\end{tabular}

Capital Cost/kW 0

Replacement Cost IDR $1,400,000$

O\&M Cost 0

Based on the existing condition of Salemo island electrical system, further simulation is conducted with the operation dispatch strategy load following (LF), where this strategy is based on the operation of diesel only to meet the needs of the system load, without charging on the side of the battery, but battery charging obtained from the output SPP.

The determination of system options is based on the following conditions:

a. Simulation using existing operating system data namely SPP Salemo with a capacity of 150 $\mathrm{kWp}$, Diesel $100 \mathrm{~kW}$ operates 12 hours with a load of operating daylight for 1 feeder.

b. Simulation using existing data assumptions taking into account the age of the system and 
current load conditions, namely by adding and replacing components of SPP system.

The system options as referred to above are presented in the table 2 below.

Table 2. System Options

\begin{tabular}{|l|c|c|c|c|c|c|}
\hline \multicolumn{1}{|c|}{ Item } & 1 & 2 & 3 & 4 & 5 & 6 \\
\hline Diesel Operation (Hour) & 12 & 24 & 24 & 24 & 24 & 24 \\
\hline Load & 1 Line & 2 Line & 2 Line & 2 Line & 2 line & 2 line \\
\hline SPP Capacity & 150 & 150 & 150 & 150 & 150 & 150 \\
\hline SPP Upgrade Capacity & & & 50 & 150 & 200 & 200 \\
\hline Diesel Capacity & 100 & 100 & 100 & 100 & 100 & 100 \\
\hline Battery Capacity & 120 & 120 & 120 & 120 & 120 & 240 \\
\hline Inverter Capacity & 80 & 80 & 80 & 80 & 80 & 80 \\
\hline Controller & CC & LF & LF & LF & LF & LF \\
\hline
\end{tabular}

\section{Results and Discussion}

Option 1 is an existing electricity system of Salemo Island in 12-hour diesel operation conditions with a load of $439.5 \mathrm{MWh} / \mathrm{yr}$. In this system option, the value of NPC is 14.5 billion with LCOE of $2,862 \mathrm{Rp} / \mathrm{kWh}$ with dispatch of control cycling operations, means that the battery discharged by diesel, therefore, there is an excess electricity of $145.7 \mathrm{MWh} / \mathrm{yr}$ operating cost value that reaches 1.19 million which when compared to option 2 operating cost value of 1.21 million at LCOE value of 2,291 Rp/kWh, which operates at load conditions of $557.7 \mathrm{MWh} / \mathrm{yr}$ as shown in the Table 3.

Based on the Figure 7, it appears that the lowest NPC is in option 6 by about IDR 8.4 million with an LCOE value of $1,306 \mathrm{IDR} / \mathrm{kWh}$, while options 4 and 5 show insignificant differences in both NPC and LCOE values whereas the difference in these two system options lies in the additional plots capacity with a difference of $50 \mathrm{kWp}$. So if we compare between options 4 and 5, significant differences lies in the capital cost with a difference of IDR 420 million.

Table 3. Comparison of Existing operating options

\begin{tabular}{|l|r|r|}
\hline \multirow{2}{*}{ Item Option } & \multicolumn{2}{c|}{ Value } \\
\cline { 2 - 3 } NPC (million) & \multicolumn{1}{c|}{1} & \multicolumn{1}{c|}{$\mathbf{2}$} \\
\hline Capital Cost & $\mathbf{7 6 8 , 0}$ & $14.796,6$ \\
\hline Operating Cost (Million) & 1.191 & $\mathbf{7 6 8}$ \\
\hline LCOE & 2.862 & 2.211 \\
\hline AC Load(MWh/Yr) & 439,5 & 557,7 \\
\hline Excess Electricity & 145,7 & - \\
\hline Total & 593,5 & 579,3 \\
\hline
\end{tabular}

DOI : $\underline{\text { http://dx.doi.org/10.31963/intek.v8i2.2962 }}$

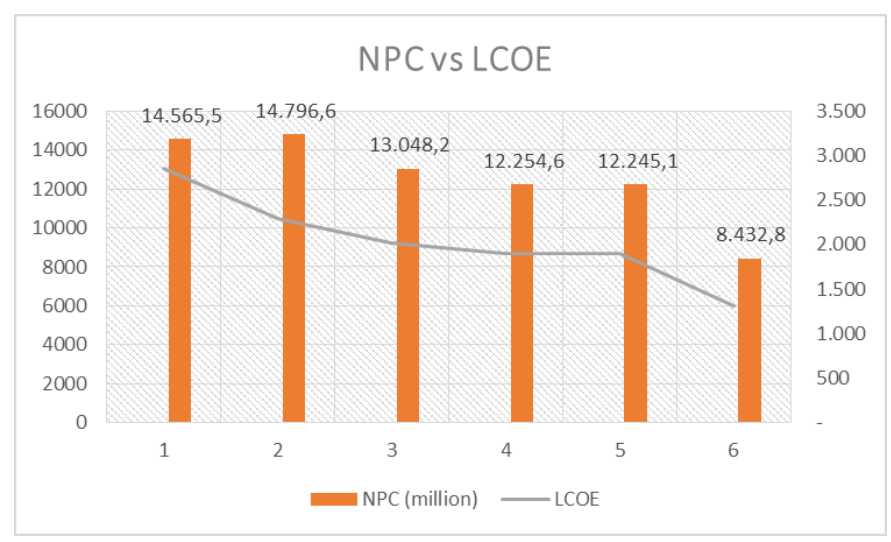

Figure 7. Comparison of NPC and LCOE

Furthermore, by comparing 3 parameters between the values of capital cost, LCOE and operating cost as shown in the figure 8 it appears that in options 1 and 2 although the capital cost value is low but the operational value is quite high, so the system option 2 is better from the LCOE aspect than option 1. While for option 3 tends to be more moderate than other options because it is relatively comparable between the three parameters compared to other options.

While for options 4 and 5 as previously stated in the previous exposure that when compared between the two options, then option 4 is better than the capital cost aspect, where the parameters of operating cost and LCOE have no significant effect.

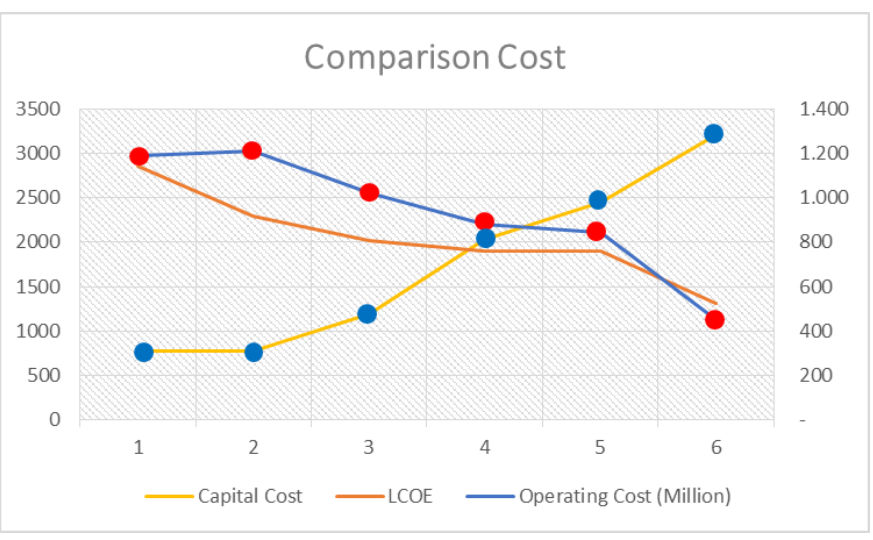

Figure 8. Comparison Cost 


\section{Conclusion}

1. For the current load and system conditions on Salemo Island, it is necessary to upgrade the system and capacity.

2. The addition of SPP capacity of $200 \mathrm{kWp}$ and battery capacity of 120 units is the most optimal option with LCOE value of $1,306 \mathrm{IDR} / \mathrm{kWh}$.

3. Another option that is best with a low capital cost value of IDR 2.02 Billion is the addition of SPP capacity of $150 \mathrm{kWh}$.

\section{References}

[1] H. S. A. Mageed, "Cost Analysis and Optimal Sizing of PVDiesel Hybrid Energy Systems", American Journal of Renewable and Sustainable Energy, Vol. 4, No. 3, pp. 47-55, 2018.

[2] B. Modu, A. K. Aliyu, A. L. Bukar, and M. M. M. Abdulkadir, Z. M. Gwoma, "Techno-Economic Analysis of Off-Grid Hybrid Pv-Diesel-Battery System in Katsina State, Nigeria”, Arid Zone Journal of Engineering, Technology and Environment, Vol. 14, No. 2, , pp. 317-324, 2018.

[3] A. K. Hassan and H. A. Khamis, "Design and Simulation of Hybrid System for Generation Electricity in Iraq", Global Scientific Journal of Electrical Engineering, Vol. 2, No. 1, pp. 18-26, 2021.

[4] A. Yahiaoui, K. Benmansour, and M. Tadjine, "Optimal sizing and control strategy of renewable hybrid systems PV-diesel generator-battery: Application to the case of djanet city of Algeria," Adv. Sci. Technol. Eng. Syst., Vol. 2, No. 3, pp. 485491, 2017, doi: 10.25046/aj020362.

[5] S. Rehman, "Hybrid power systems - Sizes, efficiencies, and economics," Energy Explor. Exploit., Vol. 39, No. 1, pp. 3-43, 2021, doi: 10.1177/0144598720965022.

[6] M. B. Sigalo, B. T. Nugha, and U. Rilwan, "Comparative Analysis and Simulation of a Hybrid PV/Diesel Generator/Grid System for the Faculty of Engineering Main Building, Rivers State University, Port Harcourt Nigeria.," IOSR J. Eng., Vol. 7, , pp. 37-44., September 2017.

[7] Nurmela and N. Hiron, "Optimasi kinerja sistem pembangkit hybrid," J. Energy Electr. Eng., Vol. 01, No. 01, pp. 7-11, 2019.

[8] B. Ceran, Q. Hassan, M. Jaszczur, and K. Sroka, "An analysis of hybrid power generation systems for a residential load," E3S Web Conf., Vol. 14, 2017, doi: 10.1051/e3sconf/20171401020.

[9] A. M. S. Yunus, M. Saini, M. S. Fuad, and I. Isradianto, "Simulation for Optimizing the Hybrid System of Solar Power Plant (SPP) and Diesel Power Plant (DPP) at Balang Lompo Island," INTEK J. Penelit., Vol. 7, No. 1, p. 62, 2020, doi: 10.31963/intek.v7i1.2133.
[10] F. Fazelpour, N. Soltani, and M. A. Rosen, "Economic analysis of standalone hybrid energy systems for application in Tehran, Iran," Int. J. Hydrogen Energy, Vol. 41, No. 19, pp. 77327743, 2016, doi: 10.1016/j.ijhydene.2016.01.113.

[11] Q. Hassan, M. Jaszczur, and J. Abdulateef, "Optimization of PV/WIND/DIESEL Hybrid Power System in HOMER for Rural Electrification," J. Phys. Conf. Ser., Vol. 745, No. 3, 2016, doi: 10.1088/1742-6596/745/3/032006.

[12] A. S. Aziz, M. F. N. Tajuddin, M. R. Adzman, M. A. M. Ramli, and S. Mekhilef, "Energy management and optimization of a PV/diesel/battery hybrid energy system using a combined dispatch strategy," Sustain., Vol. 11, No. 3, 2019, doi: 10.3390/su11030683.

[13] G. S. Atlas, "https://globalsolaratlas.info/map?s=4.689561,119.468774\&m=site." https://globalsolaratlas.info/map?s=4.689561,119.468774\&m=site (accessed Aug. 20, 2021). 